\title{
Effect of Citric Acid on Cadmium Ion Uptake and Stress Response of Hydroponically Grown Jute Mallow (Corchorus olitorius)
}

\section{Hassan MS ${ }^{1 *}$, Dagari MS $^{2}$ and Babayo AU ${ }^{1}$}

${ }^{1}$ Department of Chemical Sciences, Federal University Kashere, Gombe State, Nigeria

${ }^{2}$ Department of Pure and Industrial Chemistry, Federal University Gashua, Yobe State, Nigeria

\begin{abstract}
This research work investigates the possibility of improving the phytoextraction of Cd by the application of citric acid. For this purpose, plants were grown in hydroponics under controlled conditions. Addition of $1,5,10$ and 20 mg/L, Cd² significantly decreased the plant growth and biomass, and increased proline contents. The effects were dose dependent with obvious effects at higher $\mathrm{Cd}^{2+}$ concentration of $20 \mathrm{mg} / \mathrm{L}$. Application of $5 \mathrm{mM}$ citric acid (CA) significantly depressed $\mathrm{Cd}^{2+}$ uptake and its accumulation in plant roots and shoots. CA alleviated $\mathrm{Cd}^{2+}$ toxicity by reducing oxidative stress. Application of CA also enhanced the antioxidant enzymes activity alone and under $\mathrm{Cd}$ stress. The results showed that $\mathrm{Cd}^{2+}$ accumulated more in roots than the shoots and application of citric acid depressed $\mathrm{Cd}^{2+}$ uptake at all concentrations. Jute mallow (Corchorus olitorius) proved to be an effective accumulator for cadmium, however, neither concentration of citric acid showed advantages for phytoextraction of cadmium. The results showed that jute mallow is a potential plant for phytoextraction of $\mathrm{Cd}$ without the use of CA as enhancer.
\end{abstract}

Keywords: Cadmium; Citric acid; Proline; Phytoextraction; Biomass; Jute mallow (Corchorus olitorius)

\section{Introduction}

Among the heavy metals, cadmium (Cd) is a highly toxic, nonessential and carcinogenic element [1]. In plants, $\mathrm{Cd}^{2+}$ enters mainly through root uptake and is transported to above ground parts $[2,3]$. Higher $\mathrm{Cd}^{2+}$ concentration in plants caused several physiological and biochemical disorders including reduced growth and yield, nutrient uptake, changes in chloroplast ultrastructure and initiation of oxidative stress [4,5]. Food chain Cd contamination is the main source of Cd entry to human especially non-smoking general population and is the main constraint for food safety and agricultural land quality [6]. Therefore, different actions can be under taken to remediate Cd contaminated soils including in situ remediation techniques. Plant based remediation techniques are becoming more wide spread as these are environmental friendly and cost effective. Phytoremediation is a biological technique, considered for cleaned up of polluted sites because of its economical, visual advantages and extensive applicability $[7,8]$. Phytoextraction is a technique which uses plants to hyperaccumulate metals in to harvestable plants. The degree of metal, translocation from root to aerial plant parts depends upon plant species, metal and environmental conditions.

Jute mallow is tolerant to metal stress, has high biomass, the second most important source of fiber after cotton and the ability of jute mallow to give some financial benefit after harvesting makes it a potential plant for phytoextraction [9].

The objectives of the research are; to study the bioaccumulation capability of jute mallow, the stress response of jute mallow to cadmium uptake, to use jute mallow as hyperaccumulator and the possibility of using jute mallow for phytoremediation.

\section{Materials and Methods}

\section{Growth conditions and treatments}

Eight week old seedlings of Jute mallow (Corchorus olitorius) were collected from the Department of Agronomy farm, Bayero University, Kano on Thursday $20^{\text {th }}$ November, 2014 by $9.00 \mathrm{am}$. After washing with tap water to remove the soil, they were rinsed with deionise water and replanted in hydroponic solution. They were carefully monitored in a greenhouse for ten days under the conditions: $65 \%$ relative humidity, 14 hrs per day, $10 \mathrm{hrs}$ per night under a light intensity of $600 \mu \mathrm{mol} \mathrm{m}^{-2} \mathrm{~s}^{-1}$, and average temperatures $39 / 24^{\circ} \mathrm{C}$ [10]. Hoagland nutrient solution was used in the experiment which was made of $5 \mathrm{mM} \mathrm{KNO}_{3} ; 5 \mathrm{mM}$ $\mathrm{Ca}\left(\mathrm{NO}_{3}\right)_{2} ; 1 \mathrm{mM} \mathrm{KH} \mathrm{PO}_{4} ; 2 \mathrm{mM} \mathrm{MgSO} ; 46.3 \mu \mathrm{M} \mathrm{H}_{3} \mathrm{BO}_{3} ; 11.8 \mu \mathrm{M}$ $\mathrm{MnCl}_{2} .4 \mathrm{H}_{2} \mathrm{O} ; 0.7 \mu \mathrm{M} \mathrm{ZnSO}_{4} .7 \mathrm{H}_{2} \mathrm{O} ; 0.32 \mu \mathrm{M} \mathrm{CuSO}_{4} .5 \mathrm{H}_{2} \mathrm{O} ; 0.16 \mu \mathrm{M}$ $\mathrm{H}_{2} \mathrm{MoO}_{4} \cdot \mathrm{H}_{2} \mathrm{O}$, and $12.5 \mu \mathrm{M}$ Fe-EDTA. The treatments consisted of five Cd dosages $(0,1,5,10$, and $20 \mathrm{mg} / \mathrm{L})$ supplied as $\mathrm{Cd}\left(\mathrm{NO}_{3}\right)_{2} \cdot 4 \mathrm{H}_{2} \mathrm{O}$. In the second phase, $5 \mathrm{mM}$ of CA were added while varying the concentrations of $\mathrm{Cd}^{2+}$ from $(0,1,5,10$, and $20 \mathrm{mg} / \mathrm{L})$. Each treatment was triplicated and allowed to stand for ten days. The plants were harvested from the hydroponic solution and washed with tap water, rinsed with $1 \% \mathrm{HNO}_{3}$ followed by deionised water and then wiped with tissue paper. They were then dried in an oven at $65^{\circ} \mathrm{C}$. The weight of each plant harvested was recorded. The plants were then sorted into roots and shoots.

\section{Measurement of heavy metal content and statistical analysis}

The roots and shoots of the various plants harvested were ground to fine powder. Based on availability, $0.5 \mathrm{~g}$ (root) and $1.0 \mathrm{~g}$ (shoot) were used for the analysis. They were weighed into porcelain crucibles and ashed at $450^{\circ} \mathrm{C}$ in a muffle furnace to constant weight. The ash was dissolved in $0.1 \mathrm{moldm}^{-3}$ nitric acid, filtered and made to mark in a 50 $\mathrm{cm}^{3}$ volumetric flasks. The plants extracts and blank were stored at low temperature before analysis [11].

The concentration of $\mathrm{Cd}$ in plant root and shoot were determined by using atomic absorption spectrometer (model PG990). Analysis of

*Corresponding author: Hassan MS, Department of Chemical Sciences, Federal University Kashere, Gombe State, Nigeria, Tel: 08060726280/08088719623; E-mail: sanninmc@yahoo.com

Received April 14, 2016; Accepted May 27, 2016; Published May 31, 2016

Citation: Hassan MS, Dagari MS, Babayo AU (2016) Effect of Citric Acid on Cadmium Ion Uptake and Stress Response of Hydroponically Grown Jute Mallow (Corchorus olitorius). J Environ Anal Toxicol 6: 375. doi:10.4172/2161 0525.1000375

Copyright: @ 2016 Hassan MS, et al. This is an open-access article distributed under the terms of the Creative Commons Attribution License, which permits unrestricted use, distribution, and reproduction in any medium, provided the original author and source are credited. 
Citation: Hassan MS, Dagari MS, Babayo AU (2016) Effect of Citric Acid on Cadmium Ion Uptake and Stress Response of Hydroponically Grown Jute Mallow (Corchorus olitorius). J Environ Anal Toxicol 6: 375. doi:10.4172/2161-0525.1000375

Page 2 of 4

variance (ANOVA) using the SPSS software was performed to check the accuracy and validity of the results. Data were expressed as mean followed by SD. Statistical significance was assumed at $\mathrm{P}<0.05$.

\section{Determination of proline in plant shoots and statistical analysis}

The proline content in the shoots was determined by the method recommended by Bates et al. [12]. The concentration of proline in plant shoots was determined by using UV/Visible spectrophotometer (model T60). Analysis of variance (ANOVA) using the SPSS software was performed to check the accuracy and validity of the results. Data were expressed as mean followed by SD. Statistical significance was assumed at $\mathrm{P}<0.05$.

\section{Results and Discussion}

\section{Cadmium concentration and uptake by jute mallow}

Cadmium concentrations in roots and shoots (leaf and stem) of Jute mallow plants were significantly increased $(\mathrm{p}<0.05)$, when plants were exposed to Cadmium at varied concentrations $(1,5,10$ and $20 \mathrm{mg} / \mathrm{L})$ relative to the control plants (Figure 1). Cadmium concentration in roots and shoots gradually increased with increasing $\mathrm{Cd}$ concentration in the Hydroponic treatment.

The concentration was largest in the roots than the shoots correspondingly. Interestingly, application of Citric acid at constant concentration $(5 \mathrm{mM})$ significantly decreased $(\mathrm{p}<0.05), \mathrm{Cd}$ concentrations in roots and shoots as compared to respective only $\mathrm{Cd}$ treated plants (Figure 1).

Regardless of the different treatment, the roots parts, were the plant most accumulation areas, while concentrations in other parts were in decrease sequence Root $>$ Shoot.

The changes in translocation factor (TF) and bioaccumulation factor (BCF) against the concentrations of added $\mathrm{Cd}^{2+}$ are shown in Figures 2 and 3.

According to Chen et al. [13], translocation factor (TF) is the ratio of the concentration of a metal in the aerial part of a plant divided by the concentration in the root. In this study, the ratio can be used to evaluate the translocation effects of Jute mallow (Corchorus olitorious) seedlings replanted in hydroponic solutions. TF varied significantly with concentration of added $\mathrm{Cd}^{2+}(P<0.05)$. Thus, a relatively good fraction of the $\mathrm{Cd}^{2+}$ was translocated to the shoots (Figure 2).

The bioconcentration factor $(\mathrm{BCF})$ is the metal concentration in the root divide by the concentration of the solution. The value was used in this research to explain the uptake of $\mathrm{Cd}^{2+}$ ion by Jute mallow (Corchorus olitorious) from the solution to its root. The BCF showed that the bulk concentrations of $\mathrm{Cd}^{2+}$ remained in the roots (Figure 3 ).

\section{Effects of cadmium and citric acid on proline contents of jute mallow}

Proline contents significantly increased $(\mathrm{p}<0.05)$, when Plants were exposed to Cadmium at varied concentrations $(1,5,10$ and $20 \mathrm{mg} / \mathrm{L})$ relative to the control plants. Addition of constant concentration of CA $(5 \mathrm{mM})$, significantly decreased $(\mathrm{p}<0.05)$ the proline content in plants as compared to respective only $\mathrm{Cd}^{2+}$ treated plants (Figure 4).

\section{Discussion}

In the present study, $\mathrm{Cd}^{2+}$ induced oxidative stress as shown by increase in proline production (Figure 4). Larger production of MDA under cd stress has also been reported in B. napus L. seedlings [14] and tomato [15]. The result suggested that reactive oxygen species (ROS) might be produced in Jute mallow plant under $\mathrm{Cd}^{2+}$ stress and cause lipid peroxidation, as evidenced by the increased of shoots proline.

Exposure of plants to non-redox reactive metals also resulted in oxidative stress as indicated by lipid peroxidation, $\left(\mathrm{H}_{2} \mathrm{O}_{2}\right)$ accumulation, and an oxidative burst. Available data suggest that $\mathrm{Cd}$, when not detoxified rapidly enough, may trigger, via disturbance of the redox control of the cell, a sequence of reactions leading to growth inhibition, stimulation of secondary metabolism, lignification, and finally cell death.

By contrast, CA plus $\mathrm{Cd}^{2+}$ addition significantly $(\mathrm{p}<0.05)$, prevented proline accumulation, when compared with the $\mathrm{Cd}^{2+}$ treatment alone, suggesting a protective role of CA in preventing oxidative stress in Jute mallow. $\mathrm{Cd}^{2+}$ cannot directly produce ROS [16]. Plants usually face oxidative damage when in contact with $\mathrm{Cd}^{2+}$ and other metals [17].

The $\mathrm{Cd}^{2+}$ concentration and uptake by Jute mallow increased in roots and above ground parts with increasing $\mathrm{Cd}^{2+}$ levels in the nutrient solution (Figure 1). These results are in line with the previous findings in some plants like B. napus $L$. $[18,19]$.

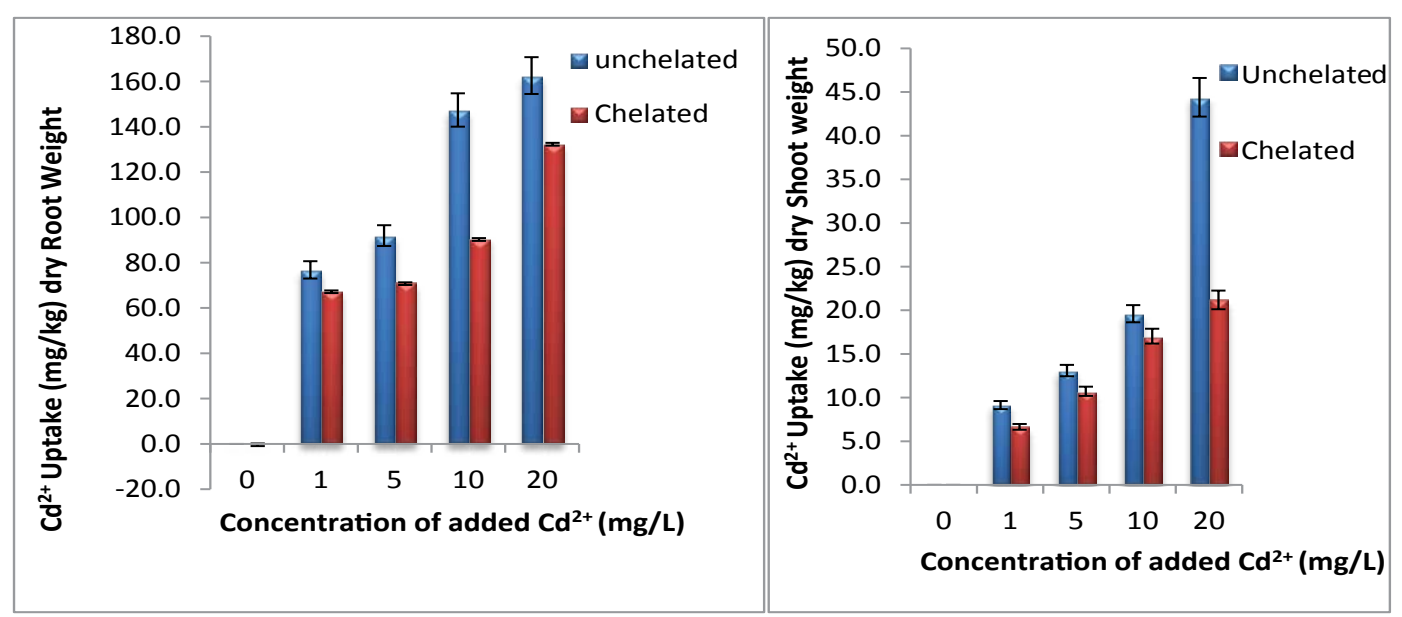

Figure 1: Total $\mathrm{Cd}^{2+}$ uptake by Unchelated (treatment without citric acid) and Chelated (treatment with citric acid (5mM)) hydroponically grown Jute mallow (Corchorus olitorious). 


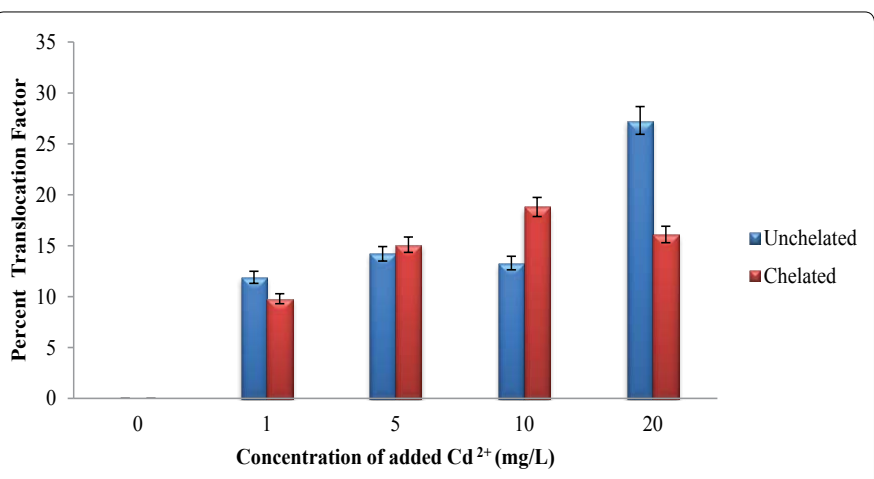

Figure 2: Translocation Factor (T.F) of $\mathrm{Cd}^{2+}$ in Jute mallow grown in Unchelated (treatment without citric acid) and chelated (treatment with citric acid $(5 \mathrm{mM})$ ).

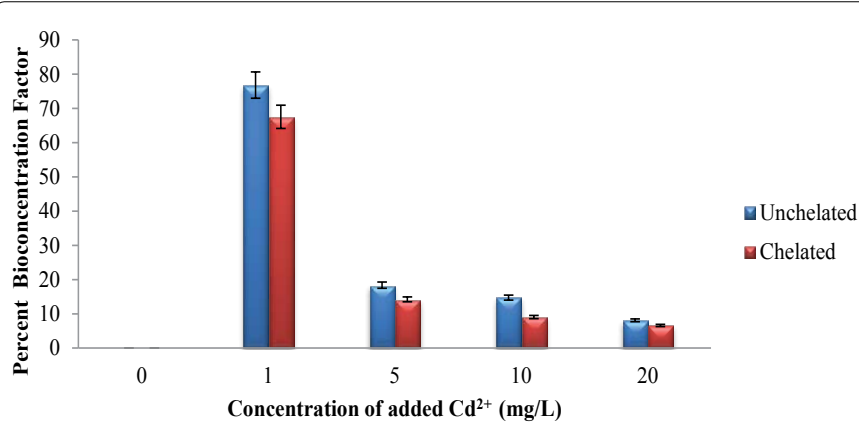

Figure 3: Bioconcentration Factor (BCF) of $\mathrm{Cd}^{2+}$ in Jute mallow grown in Unchelated (treatment without citric acid) and Chelated (treatment with citric acid $(5 \mathrm{mM}))$.

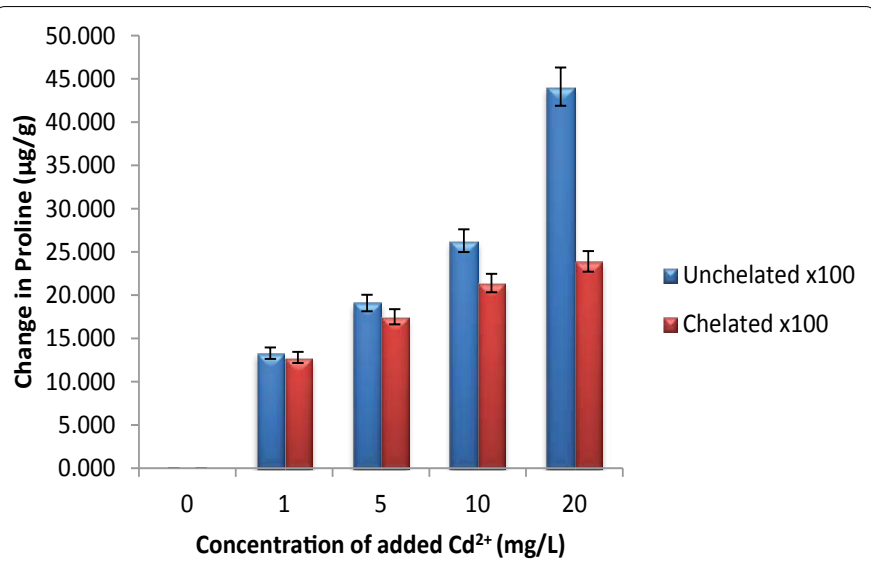

Figure 4: Proline accumulation in shoot of Jute mallow (Corchorus olitorious) seedlings.

Interestingly, application of $\mathrm{CA}$ at $(5 \mathrm{mM})$ increased $\mathrm{Cd}^{2+}$ concentration and uptake by the plants as compared to the control, but decreased $\mathrm{Cd}^{2+}$ concentration and uptake by the plants as compared to the Cd treated plants (Figure 1). Reduced uptake might be due to the reason that $\mathrm{Cd}$ is highly soluble and bioavailable, whereas citric acid might transform the exchangeable Cd to relatively stable organic and residual forms. The distribution of metals with plant tissues is an important property that can act as an indirect indicator of detoxification mechanism. In present study, $\mathrm{Cd}^{2+}$ accumulation were lower, less than $500 \mathrm{mg} / \mathrm{kg}$ with the highest $\mathrm{Cd}^{2+} 20 \mathrm{mg} / \mathrm{L}$, level in the nutrient solution in the whole Jute mallow plants.
Cadmium concentration in shoots of B. napus $L$. has been reported up to $555 \mathrm{mg} / \mathrm{kg}$ dry weight only on exposure for fifteen days and about $240 \mathrm{mg} / \mathrm{kg}$ dry weight only on exposure for ten days in solution [14].

Cadmium concentration in plants varies with type, genotype and duration of $C d$ exposure to plants as of B. napus L. [18] and $B$. juncea [5]. It has been reported that plant may have no limitation of Cd uptake until Cd caused significant damage to plants [19-21]. Upper threshold of Cd accumulation in Jute mallow has not been shown and further study is required in order to investigate the limitation of $\mathrm{Cd}$ accumulation in plants. In present study, duration of plant exposure to Cd was short, ten days and CA application enhanced antioxidant enzyme activity and gas exchange parameters which may increase $\mathrm{Cd}$ in the shoots and roots. Moreover, Jute mallow may accumulate relatively high $\mathrm{Cd}$ in shoots and roots after a long term exposure, judging from the growth characteristics being exhibited by the plants. However, further research is required to evaluate, the Jute mallow ability to uptake $\mathrm{Cd}^{2+}$ from the soil especially with CA application and its utilization as a hyperaccumulator.

\section{Conclusion}

In conclusion, the results indicated that $\mathrm{Cd}^{2+}$ supply significantly depressed plant growth and biomass. $\mathrm{Cd}^{2+}$ accumulated more in roots than the shoots. Addition of $5 \mathrm{mM} \mathrm{CA}$ alleviated $\mathrm{Cd}^{2+}$ toxicity by reducing oxidative stress, through CA chelating property and increased antioxidant capacity when compared with $\mathrm{Cd}^{2+}$ treatment alone. Jute mallow (Corchorus olitorius) proved to be an effective accumulator for cadmium, in the range 0 to $20 \mathrm{mg} / \mathrm{L}$. The concentration of citric acid $(5 \mathrm{mM})$ did not show any advantages for phytoextraction of cadmium. The results can be beneficial to the society in the monitoring of areas contaminated by heavy metals as a result of mining and industrial activities.

\section{Acknowledgements}

My acknowledgement goes to the Head of Plant Biology Department, Mr. Joseph of Pure and Industrial Chemistry, and Sama'ila Ibrahim of Agronomy Department, Bayero University, Kano who made invaluable contribution to the success of this research.

\section{References}

1. Bavi K, Kholdebarin B, Moradshahi A (2006) Effect of cadmium on some of the biochemical and physiological processes in bean plants. Am J Plant Physiol 1: $177-184$

2. Chakroun HK, Souissi F, Bouchardon JL, Souissi R, Moutte J, et al. (2010) Transfer and accumulation of lead, zinc, cadmium and copper in plants growing in abandoned mining-district area. Afr J Environ Sci Tech 4: 651-659.

3. Ehsan S, Ali S, Noureen S, Mahmood K, Farid M, et al. (2014) Citric acid assisted phytoremediation of cadmium by Brassica napus L. Ecotoxicol Environ Saf 106: 164-172.

4. Anwer S, Ashraf MY, Hussain M, Ashraf M, Jamil A (2012) Citric acid mediated phytoextraction of cadmium by Maize (Zea Mays L.). Pak J Bot 44: 1831-1836.

5. Gill SS, Khan NA, Tuteja N (2011) Differential cadmium stress tolerance in five indian mustard (Brassica juncea L.) cultivars: an evaluation of the role of antioxidant machinery. Plant Signal Behav 6: 293-300.

6. Wuana RA, Okieimen FA, Imborvungu JA (2010) Removal of heavy metals from a contaminated soil using organic chelating acids. Int J Environ Sci Tech 7: 485-496.

7. Muhammad D, Chen F, Zhao J, Zhang G, Wu F (2009) Comparison of EDTAand citric acid-enhanced phytoextraction of heavy metals in artificially metal contaminated soil by Typha angustifolia. Int J Phytoremediation 11: 558-574.

8. Najeeb U, Jilani G, Ali S, Sarwar M, Xu L, et al. (2011) Insights into cadmium induced physiological and ultra-structural disorders in Juncus effusus $L$. and its remediation through exogenous citric acid. J Hazard Mater 186: 565-574. 
Citation: Hassan MS, Dagari MS, Babayo AU (2016) Effect of Citric Acid on Cadmium Ion Uptake and Stress Response of Hydroponically Grown Jute Mallow (Corchorus olitorius). J Environ Anal Toxicol 6: 375. doi:10.4172/2161-0525.1000375

Page 4 of 4

9. Sun Q, Ye ZH, Wang XR, Wong MH (2007) Cadmium hyperaccumulation leads to an increase of glutathione rather than phytochelatins in the cadmium hyperaccumulator Sedum alfredii. J Plant Physiol 164: 1489-1498.

10. Parmar P, Kumari N, Sharma V (2013) Structural and functional alterations in photosynthetic apparatus of plants under cadmium stress. Bot Stud 54: 45

11. Zhang G, Wu K, Dong Q, Dai F, Chen F, et al. (2006) Cd stress in higher plants In: Khan, Samiullah NA (Ed.). Cd toxicity and Tolerance in Plants. Narosa Publishers, pp: 87-101.

12. IITA (International Institute of Tropical Agriculture) (1979) Laboratory manual on basic Soil and Plant Analyses. Longman London, UK, pp: 9-67.

13. Bates LS, Walden RP, Teare ID (1973) Rapid determination of free proline for water stress studies. Plant and soil 39: 205-207.

14. Chen YX, Lin Q, Luo YM, He YF, Zhen SJ, et al. (2003) The role of citric acid on the phytoremediation of heavy metal contaminated soil. Chemosphere 50 : 807-811.

15. Meng H, Hua S, Shamsi IH, Jilani G, Li Y, et al. (2009) Cd-induced stress on the seed germination and seedling growth of Brassica napus $L$. and its alleviation through exogenous plant growth regulators. Plant Growth Regul 58: 47-59.
16. Haouari CC, Nasraoui AH, Bouthour D, Houda MD, Daieb CB, et al. (2012) Response of tomato (Solanum lycopersicon) to cadmium toxicity: growth element uptake, chlorophyll content and photosynthesis rate. Afr J Plant Sci 6: $1-7$.

17. Zhang FQ, Zhang HX, Wang GP, Xu LL, Shen ZG (2009) Cadmium induced accumulation of hydrogen peroxide in the leaf apoplast of Phaseolus aureus and Vicia sativa and the roles of different antioxidant enzymes. J Hazard Mater 168: 76-84.

18. MacFarlane GR (2003) Chlorophyll a fluorescence as a potential biomarker of zinc stress in the grey mangrove, Avicennia marina (Forsk.) Vierh. Bull Environ Contam Toxicol 70: 90-96.

19. Ghani A (2011) Varietal differences in canola (Brassica napus L.) for the growth, yield and yield components exposed to cadmium stress. J Anim Plant Sci 2: 57-59.

20. Park J, Kim JY, Kim KW (2012) Phytoremediation of soil contaminated with heavy metals using Brassica napus. Geosyst Eng 15: 10-18.

21. Arabi Z, Homaee M, Asadi ME (2011) Comparison effects of citric acid and synthetic chelators in enhancing phytoremediation of cadmium. J Sci Technol Agric Natural Resources 14: 85-95 